\section{Hyperphagia caused by Cerebral Ventricular Infusion of Phloridzin}

WE report here an experiment which seems to provide definite proof that the hypothalamic feeding mechanism contains glucorcceptors controlling satiety. That such glucoreceptors exist, and are different metabolically from other brain tissue, had been suggested indirectly by studies relating hunger and gastric contractions to the utilization of glucose ${ }^{1}$ and by work on goldthioglucose. Single injections of this compound cause lesions in the ventromedial area of the hypothalamus ${ }^{2}$. The action is specific chemically: glucose and not similar metabolites has to be a part of the molecule ${ }^{3}$. It is specific anatomically: induced weakness of the blood-brain barrier in other cerebral areas does not increase permeability to this compound ${ }^{4}$. Goldthioglucose destroys cells the axons of which connect the ventromedial area to the lateral area, and cells at the origin of Schultze's bundle-a structure which links the hypothalamus to the roots of the vagus ${ }^{4}$. The former gives an anatomical basis for the known physiological relation between the "satiety" area and the "feeding" area, the latter for the physiological role of the ventromedial area in inhibition of gastric contractions by glucagon $^{6}$ and stimulation of gastric secretion by insulin ${ }^{7}$. The action of goldthioglucose is blocked by analogues of glucose $^{8}$ and by alloxan diabetes ${ }^{9}$, the latter confirming the postulated dependency of the glucoreceptors on insulin. Anand has also shown that the electrical activity of the ventromedial area is increased when the utilization of glucose is increased and vice versa, while the lateral area shows the opposite pattern ${ }^{10}$.

In our experiment, phloridzin, a known inhibitor of glucose uptake in a wide variety of tissues (though not known, until now, to inhibit any neural tissue), was tested for similar effects in hypothalamic glucoreceptors in rats. A cerebral lateral, ventricular infusion of a $1 \times 10^{-3} \mathrm{M}$ solution at a rate of 1 to $2 \mu \mathrm{l} . / \mathrm{min}$ for 50 to $90 \mathrm{~min}$ resulted in marked hyperphagia (up to $30 \mathrm{~g}$ of Purina chow a day for $250 \mathrm{~g}$ females-double the normal intake) and gain in weight (up to $15 \mathrm{~g} /$ day).

The hyperphagic effect was transient (approximately $48 \mathrm{~h}$ ) when the rate of infusion was $1 \mu \mathrm{l} . / \mathrm{min}$ and the animals gained 15 to $30 \mathrm{~g}$ during this interval. It lasted for at least 2 weeks when the rate was $2 \mu \mathrm{l} . / \mathrm{min}$ and the animals gained up to $5 \mathrm{~g} /$ day. Intraperitoneal injections of doses of phloridzin, two to four times greater than those injected into the ventricle, had no effect on food intake. (The amount of phloridzin infused is too small to have any detectable systemic effect.) The data confirm the existence of cerebral glucoreceptors which are involved in the regulation of food intake. The presumption that they are identical to the hypothalamic receptors previously identified is boing tested experimentally.

\section{Zvi GLICK}

JEAN MAYER

Department of Nutrition.

School of Public Health,

Harvard University,

Boston, Massachusetts.

Received July 18, 1968.

Mayer, J., Ann. NY Acad. Sci., 63, 15 (1955).

Marshall, N. B., Barrnett, R. J., and Mayer, J., Proc. Soc. Exp. Biol. and Med., 90, $240(1955)$.

${ }^{3}$ Mayer, J, and Marshall, N. B., Nature, 178, 1399 (1956)

4 Mayer, J, and Arees, E. A., Fed. Proc. (in the press).

s Arees, F. A., and Maycr, J., Science, 15\%, 1574 (1967).

${ }^{6}$ Mayer, J., and Sudsaneh, S., Amer. J. Physiol., 197, 274 (1959).

Ridley, P. T., and Brooks, H. B., Amer. J. Physiol., 209, 319 (1965).

${ }^{8}$ Likuski, H. J., Debons, A. F,, and Choutier, R. J., Amer. J. Physiol., 212, 669 (1967).

${ }^{9}$ Debons, A. J., Krimsky, I., Likuski, H. J., From, A., and Cloutier, R. J., Amer. $J$ Physiol, 214, 652 (1968).

"Anand, B. K., Chhina, G. S., Sharma, K. N., Dua, S., and Singh, B., Amer. J. Physiol., 207, 1146 (1964)

\section{Implications of Hyperglycaemia and Cataract in a Colony of Tuco-tucos (Ctenomys talarum)}

Spontantous diabetes mellitus occurs rarely in domestic animals ${ }^{1-2}$. It has been found in more than 10 per cent of individuals in captive colonies of the Egyptian sand rat

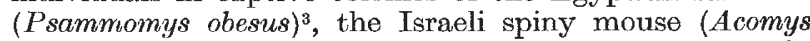
cahirinus) ${ }^{4}$, the Philippines tree shrew (Urogale everetti) ${ }^{5}$ and the squirrel monkey (Saimiri sciureus).

A colony of tuco-tucos of unknown age from a restricted locality in the province of Buenos Aires, Argentina, was established at the Wellcome Institute of Comparative Physiology. The tuco-tuco (Ctenomys talarum) is a small $(120 \mathrm{~mm})$ burrowing hystricomorph rodent. The forty males weighed $85-210 \mathrm{~g}$ (mean $166 \mathrm{~g}$ ). Many of the seventy-six females $(95-190 \mathrm{~g}$, mean $127 \mathrm{~g}$ ) were pregnant. After pregnancies lasting at least 3 months, twenty-seven litters of one to six young were born. This $F_{1}$ generation was weaned when 4 weeks old, and housed like the parent colony, one male to three females, in 0.25 in. wire mesh cages, 22 in. long, 17 in. wide and 8 in. deep. Room temperature was maintained at $20^{\circ} \mathrm{C}$; room lights were on from $08.00 \mathrm{~h}$ to $20.00 \mathrm{~h}$ and skylights provided natural daylight. Initially, each animal consumed approximately $5 \mathrm{~g}$ of compound diet pellets (Dixon, Diet 86), $10 \mathrm{~g}$ of hay, $10 \mathrm{~g}$ of carrot, $5 \mathrm{~g}$ of cabbage and $2 \mathrm{~g}$ of sunflower seeds daily.

Dense lens opacities were first observed in members of the $F_{1}$ generation at the age of 3 months and some animals appeared to be obese. The first complete eye and blood sugar assessments were carried out on all members of this generation after $2-5$ months on the diet. The animals were then subdivided randomly into two groups: twothirds received hay, sunflower seeds and pellets daily, together with cabbage and carrot three times weekly (diet $A$ ), and the remaining one-third were fed similarly, but were deprived of pellets $(\operatorname{diet} B)$. One month later, the eyes and blood sugar concentrations of the parent colony were assessed.

Qualitative and quantitative reagent strips and tablets (Ames: 'Clinitest', 'Albustix' and 'Acetest') were used for analysis of urine. A retro-orbital bleeding technique ${ }^{7}$ was used to obtain $50 \mu \mathrm{l}$. aliquots of blood which were analysed by a modified microferricyanide method with a Technicon autoanalyser ${ }^{8}$. Bleeding was carried out under brief, light halothane anaesthesia by a "bell-jar" technique which has been shown not to produce transient hyperglycaemia". Blood samples were all collected between $11.00 \mathrm{~h}$ and $13.00 \mathrm{~h}$ without food withdrawal. Both eyes of each animal were examined by direct ophthalmoscopy with or without mydriasis, using 1 per cent tropicamide ('Mydriacyl'). 'The observer (J. M. H.) was unaware of the blood sugar status of the animals. Representative lesions were photographed with a Kowa II medical camera.

A change of refractive index at the lens cquator, scen only after mydriasis, was the most minor sign of lens abnormality. Other changes included vacuolation (Fig. $l a$ and $b$ ), discrete opacities (Fig. 1c) and complete opacification of the lens (Fig. $1 d$ ). In some animals, the changes appeared sequentially. One to two months later, regressive changes were seen in some lenses (Fig. 1e).

In the $F_{1}$ generation of forty-seven animals, nineteen (40 per cent) had ono or more of these lens changes, and the distribution of blood sugar values according to lens appearance in the least affected eye of each animal is shown in Fig. 2. The blood sugar concentration (mean $\pm S . D$. .) for the group with the normal lenses was $101 \pm 34$ $\mathrm{mg}$ per cent, compared with $150 \pm 30 \mathrm{mg}$ per cent for the group showing vacuoles $(t=2.79,0.001<P<0.01)$ and $174 \pm 58 \mathrm{mg}$ per cent for the group with more advanced cataractous changes $(t=5 \cdot 79, P=0 \cdot 00 \mathrm{I})$. There was a highly significant correlation between blood sugar level and weight at the time of sampling $(r=0.61, P=0.001)$, 